\title{
Разработка системы показателей качества и технологических свойств в цепочке «виноград - сусло - виноматериал - вино», дифференцирующей вина Крыма по географическому происхождению
}

\author{
Елена Викторовна Остроухова, д-р техн. наук, ст. науч. сотр., гл. науч. сотр. лаборатории тихих вин, \\ elenostroukh@gmail.com; \\ Ирина Валериевна Пескова, канд. техн. наук, ст. науч. сотр., вед. науч. сотр. лаборатории тихих вин, уаrinka-73@mail.ru; \\ Полина Александровна Пробейголова, канд. техн. наук, ст. науч. сотр. лаборатории тихих вин, polina_pro5@mail.ru; \\ Наталия Юрьевна Луткова, мл. науч. сотр. лаборатории тихих вин, lutkova1975@mail.ru \\ Федеральное государственное бюджетное учреждение науки «Всероссийский национальный научно-исследовательский институт \\ виноградарства и виноделия «Магарач» РАН», ул. Кирова 31, Ялта 298600, Российская Федерация
}

\begin{abstract}
Работа посвящена совершенствованию системы контроля производства белых столовых вин с географическим статусом. Исследован химический состав, биохимические свойства и физико-химические характеристики объектов контроля в цепочке «виноград-сусло-виноматериал-вино» по пяти регионам Крыма. Использованы общепринятые и разработанные методы энохимического анализа, включая ВЭЖХ; дисперсионный, кластерный и дискриминантный методы статистического анализа данных программы SPSS Statistica 17. Выявлены параметры винограда, виноматериалов и вин, отражающие особенности их углеводнокислотного и фенольного комплексов, оксидазной системы и различающиеся $(\alpha<0,05)$ по почвенно-климатическим районам производства объектов. Оценена роль природных факторов в формировании параметров объектов и их взаимосвязь. Разработана система параметров качества и технологических свойств винограда, виноматериалов и вин, в совокупности дифференцирующих (Wilks L. $<0,094, \alpha<0,0004$, ошибка $<5 \%$ их по географическому происхождению. Система параметров предлагается для контроля и управления формированием отличительных качественных признаков белых столовых вин, обусловленных районом произрастания винограда.
\end{abstract}

Ключевые слова: виноград; вино; качество; район произрастания; географический статус; показатели; контроль.

$\mathrm{B}$ ведение. ОАной из актуацьных заАач российской виноградарсковинодельческой отрасли является развитие виноделия с географическим статусом, ориентированного на выпуск конкурентоспособных вин с уникальны-

\footnotetext{
Как цитировать эту статью:

Остроухова Е.В., Пескова И.В., Пробейголова П.А. Луткова Н.Ю. Разработка системы показателей качества и технологических свойств в цепочке «виноград - сусло - виноматериал - вино», дифференцирующей вина Крыма по географическому происхождению // вина Крыма по географическому происхождению // C.250-255. DOI 10.35547/IM.2019.21.3.012

How to cite this article:

Ostroukhova E.V., Peskova I.V., Probeigolova P.A., Lutkova N.Yu. Development of a system of indicators of quality and technological properties in the chain "grapesmust-wine material-wine" that differentiate Crimean must-wine material-wine that differentiate Crimean
wines by geographical origin. Magarach. Vinogradarstvo $i$ vinodelie=Magarach. Viticulture and Winemaking. 2019, 21(3):250-255. DOI 10.35547/IM.2019.21.3.012 (in Russian)

удК 663.253.1

Поступила 08.08.2019

Принята к публикации 20.08.2019

(C)Авторы, 2019
}

OR I G I N A L R E S E A R C H

Development of a system of indicators of quality and technological properties in the chain "grapes-must-wine material-wine" that differentiate Crimean wines by geographical origin

Elena Viktorovna Ostroukhova, Irina Valerievna Peskova, Polina

Aleksandrovna Probeigolova, Natalia Yurievna Lutkova

Federal State Budget Scientific Institution All-Russian National Research Institute of Viticulture and Winemaking Magarach of the RAS, Kirova Str. 31, Yalta 298600, Russian Federation

The paper discusses the improvement of production control system over white table wines with geographical status. We studied the chemical composition, biochemical and physicochemical characteristics of the control objects in the chain "grapes-must-wine material-wine" for 5 regions of Crimea. Standard and developed methods for eno-chemical analysis of objects were applied, including HPLC; SPSS Statistica 17 ANOVA, cluster and discriminant analyzes. Parameters of grapes, wine materials and wines were determined reflecting peculiarities of their carbohydrate-acid and phenolic complexes, oxidase system and differing $(\alpha<0.05)$ by soil-climatic regions of object origin. The role of natural factors in parameter formation was assessed along with their correlation. A system of parameters of quality and technological properties was developed for grapes, wine materials and wines that in the aggregate differentiate (Wilks L. $<0.094, \alpha<0.0004$, error $<5 \%$ ) them by their geographical origin. We suggest to use this system of parameters to monitor and control formation of distinctive quality characteristics of white table wines, determined by the region of grapevine growth.

Key words: grapes; wine; quality; growth area; geographical status; indicators; control.

ми качественными характеристиками, обусловленными происхожАением, вкцючая природные условия произрастания винограАа и антропогенные факторы производства.

Важным аспектом решения этой задачи явцяется создание научно обоснованной системы контромя качества и происхождения в цепочке «винограА - сусло - виноматериал - вино». Как показывает анациз митературных сведений, современные исследования в этом направ ении акцентируются на поиске решений Аһя иАентификации происхожАения готовой продукции. В качестве иАентифицирующих критериев преАлагаются показатели, как непосреАственно связанные с качественными характеристиками винопродукции (в частности, компоненты углеводно-кислотного $[1,2]$, феномьного $[3,4]$, ароматобразующего $[5,6]$ комплексов), так и показатели, взаимосвяь которых с качеством продукции весьма опосредована ими не доказана (аминокислотный, катионно-анионный состав, реАкоземельные и микроэлементы [7-10], соотношениz изотопов ${ }^{87} \mathrm{Sr} /{ }^{86} \mathrm{Sr},{ }^{13} \mathrm{C} /{ }^{12} \mathrm{C},{ }^{18} \mathrm{O} /{ }^{16} \mathrm{O}[11-13]$ и Ар. Чаще всего современнные подходы к иАентификации происхожАения вин базируются на измерении системы показатемей [14-16].

Проблемным остается вопрос контроля отличитемьных качественных признаков вин с географическим статусом в ходе всего технологического цикма производства - от сырья до готовой про- 
Аукции. А это, в свою очереАь, ограничивает возможности управцения качеством вин в зависимости от места произрастания винограда, в т.ч. обеспечения его постоянства и узнаваемости из года в гоА. ИсслеАования в этом направ ении явцяются актуацьными и в настоящей пубцикации рассматриваются в отношении бемых столовых вин.

Цемь работы - систематизация и статистическая обработка экспериментацьных данных по составу и технологическим свойствам винограда и вин из разных почвенно-кмиматических районов Крыма; выявмение показателей, разцичающихся по району происхожАения объектов; установ ение взаимосвязи параметров в цепочке «винограА - сусло - виноматериал - вино» как базиса Аля контроця происхожАения и управления формированием отмичительных признаков белых столовых вин с географическим статусом в технологическом цикме.

\section{Объекты и методы исследований}

Методической основой исследований явцямось природное районирование Крыма в соответствии с [13]. КАиматические характеристики районов привеАены в [17]. В экспериментацьной работе испоцьзовали объекты исследований из южнобережного (I), горно-долинного (II), горно-Аолинного приморского (III) районов Южнобережной зоны; западного преАгорно-приморского (VI) района Предгорной зоны; западного приморско-степного (VIII) района Степной зоны. Объектами исслеАований явмямись:

- винограА по ГОСТ 31782 - всего 217 партий 34 белых кмассических (Амиготе, Шардоне, Мускат белый и Ар.), крымских автохтонных (Кокур бемый, Сары пандас и Ар.) и селекционных (Первенец Магарача, Подарок Магарача и Ар.) сортов 2006-2018 гг. урожая;

- бемые сортовые сухие виноматериамы по ГОСТ 32030, полученные в условиях микровинодемия согласно [18] с использованием чистых культур Арожжей Saccharomyces cerevisiae из Центра комлективного помьзования «Комчекция микроорганизмов винодемия «Магарач» - 135 образцов.

Апробацию выявменных параметров винограда и вин, Аифференцирующих их по району произрастания винограда, проводими на образцах белых сто-

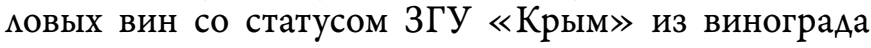
урожая 2017 г. крымских производитемей: хомАинг «Inkerman International» (запаАный преАгорно-приморский район), АО «Старокрымский» (восточнопреАгорный район), АО «Солнечная Аолина» (горно-Аолинный приморский район).

Спектр рассматриваемых в настоящей работе показателей объектов охватывац компонентный состав и технологические характеристики углеводнокислотного и фенольного комплексов, оксидазной системы; оптические характеристики и показатели потенциометрического титрования объектов раствором йода (dEh и $\mathrm{dEh} / \Phi \mathrm{B})$; концентрацию глицерина. Выбор контролируемых показателей объясняется слеАующим. С одной стороны, как показали ранее проведенные исследования, перечисленные компоненты и свойства сырья и виноматериалов в значительной мере обусловливают формирование органомептического качества готовой продукции, как на стадии созревания винограда, так и в процессе производства вин и рекоменАуются Аһя оптимизации технологических процессов [18-23]. С Аругой стороны, комичественные и качественные характеристики угмеводнокислотного и фенольного комплекса винограда и вина существенно зависят от сорта винограда и почвеннокмиматических параметров района его произрастания $[1-3,17,24-27]$.

Энохимический анациз объектов осуществцями стандартизированными, общепринятыми и разработанными методами [20, 26]. Монофеноммонооксиге-

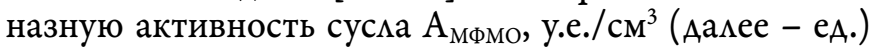
определями по скорости окисления раствора пирокатехина [28]. Массовую концентрацию органических кислот, моносахаров и глицерина опредемяли методом ВЭЖХ (хроматограф Shimadzu LC Prominence, Japan) в соответствии с прописью, преАставценной в [27]; определение глюкозы, фруктозы и глицерина провоАими на рефрактометрическом Аетекторе.

Все исследования осуществцяли в 2-3 повторностях. Экспериментацьный материац обрабатываци методами ANOVA, Аискриминантного и кмастерного анализов с использованием программы SPSS Statistics 17. Сравнение значений комичественных признаков в независимых поАгруппах проводили при помощи $\mathrm{t}$-критерия Стьюдента (Аля нормацьно распределенных по тесту Коммогорова-Смирнова признаков) ими U-критерия Манна-Уитни. Информативность Аискриминантных переменных оцениваци на основании статистики Уимкса. Оценку Аостоверности выявленных

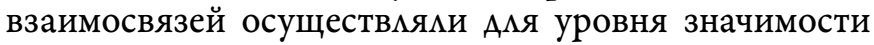
$\alpha<0,05$.

\section{Результаты и их обсуждение}

Значения показателей исследованных партий винограда, произрастающего в Крыму, а также результаты оценки значимости факторов (район/зона произрастания, сорт, год урожая и содержание сахаров) и некоторых их взаимодействий в Аисперсии параметров винограда представлены в табл. 1. Анализ Аанных табл. 1 позволяет константировать, что Аисперсия концентрации сахаров (САХ) в винограде в период промышиенного сбора в наибольшей степени предопределяется местом произрастания винограда $(\alpha<0,001)$, а также годом урожая $(\alpha=0,002)$. Факторами, обусловливающими Аисперсию величин показате$\Lambda я$ технической зрелости (ПТЗ) винограда, глюкоациАиметрического показате я (ГАП) и активной кислотности (pH), явцяются район произрастания, сорт и гоА урожая. В отношении Аисперсии содержания титруемых кислот (ТК) в винограде значимость факторов уменьшается в ряду: сорт, содержание сахаров > гоА урожая > место произрастания винограда. Отмечена значимая роль межфакторных взаимодействий (место произрастания и сорт) в формировании указанных показателей углеводно-кислотного комплекса винограда. Наибольшее влияние на разброс величины отношения концентраций глюкозы и фруктозы в винограде оказали район его произрастания и год урожая $(\alpha<0,001)$, винной и ябцочной кислот (ВК/ЯК) - сорт 
Development of a system of indicators of quality and technological properties in the chain "grapes-must-wine material-wine"...

винограда и природная зона его культивирования. Из рассматриваемых факторов только год урожая яв яется значимым в отношении формирования технологического запаса фенольных веществ (ТЗФВ) в винограде. В то же время Аисперсия степени перехода фенольных компонентов в сусло при прессовании целых ягоА $\left(Ф \mathrm{~B}_{0} / \mathrm{T} З Ф В\right)$ ими при 4-часовом настаивании мезги $\left(Ф B_{4} / \mathrm{T} З Ф В\right)$ предопредемяется годом урожая и накопиением сахаров > местом произрастания > сортом винограда. Монофеноммонооксигеназная активность сусла винограда значимо $(\alpha<0,001)$ варьирова а по годам урожая; на Аисперсию ее отношения к содержанию фенольных веществ $\left(\mathrm{A}_{\mathrm{M \Phi мо}} / Ф \mathrm{~B}_{0}\right)$, которые являются субстратами фермента, влияние оказывами сорт винограда и межфакторное взамодействие (район и САX).

В результате Аискриминантного анализа данных выявлена система показателей, в совокупности Аифференцирующих винограА по 5 районам произрастания (Wilks $L .=0,09 ; \alpha<0,0004)$ и отражающих техномогические свойства сырья (рис. 1, табц. 2). На рис. 1 представлена диаграмма рассеяния образцов винограда по районам его произрастания по 2 Аискриминантным функциям, объясняющим 87\% Аисперсии; стрелками обозначен знак (《+» или «-») корремяции значений показатемя и функции. В табл. 2 приведены средние значения ( \pm стандартное откцонение) показателей по каждому из районов.

Обобщение представленных Аанных позвомяет констатировать, что винограА из Южнобережной зоны характеризовацся наибольшими $(\alpha<0,00001)$ величинами ГАП, винограА из запаАного преАгорноприморского района - наименьшими $(\alpha<$ $0,00001)$ значениями ГАП и рН. ВинограА из восточно-преАгорного и запаАного приморско-степного районов отмичался невысокой способностью к отАаче феноцьных веществ в сусло от их технологического запаса как при прессовании целых ягод $(30 \pm 6 \%)$, так и при 4-часовом настаивании мезги $(35 \pm 12 \%)$ : в среднем в 1,7 раза $(\alpha<0,02)$ меньше таковой в винограде из Аругих районов. Высокие значения показателей, отражающих способность к экстрагированию феномьных веществ из кожицы винограда I-го и, особенно, III-го районов в процессах виноделия связаны с увеличением проницаемости кметочных стенок по мере накопиения сахаров [22], содержание которых в образцах винограда бымо наи-

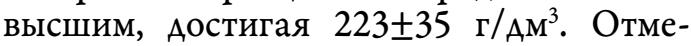
чено, что в IV и VIII районах винограА в среАнем характеризовался оптимацьными
Таблица 1. Параметры качества и технологических свойств винограда, произрастающего в Крыму, и оценка значимости факторов, их обусловливающих

Table 1. Parameters of quality and technological properties of grapes growing in Crimea, and rating significance of the factors that determine them

\begin{tabular}{|c|c|c|c|c|c|c|c|}
\hline \multirow{2}{*}{ Показатеми } & \multirow{2}{*}{ Значения ${ }^{1}$} & \multicolumn{4}{|c|}{$\begin{array}{l}\text { Факторы и уровень их значи- } \\
\text { мости }(\alpha)\end{array}$} & \multirow{2}{*}{$\begin{array}{l}\text { Рай- } \\
\text { он и } \\
\text { САХ }\end{array}$} & \multirow{2}{*}{$\begin{array}{l}\text { Район } \\
\begin{array}{l}\text { зона } \\
\text { и сорт }\end{array}\end{array}$} \\
\hline & & $\frac{\text { район }}{\text { зона }}$ & сорт & ГОА & CAX & & \\
\hline CAX, r/AM ${ }^{3}$ & $\frac{208 \pm 30}{160-250}$ & $\frac{<0,001}{<0,001}$ & 0,009 & 0,002 & - & - & 0,26 \\
\hline $\mathrm{TK}, \mathrm{\Gamma} / \mathrm{AM}^{3}$ & $\frac{6,7 \pm 1,4}{3,0-11,3}$ & $\frac{0,045}{0,008}$ & $<0,001$ & 0,002 & $<0,001$ & 0,32 & $\frac{0,09}{0,002}$ \\
\hline $\mathrm{pH}$ & $\frac{3,31 \pm 0,22}{2,75-4,28}$ & $\frac{<0,001}{<0,001}$ & $<0,001$ & $<0,001$ & 0,010 & 0,29 & $\frac{0,026}{0,015}$ \\
\hline ПТ3 & $\frac{229 \pm 55}{136-452}$ & $\begin{array}{l}<0,001 \\
<0,001\end{array}$ & $<0,001$ & $<0,001$ & $<0,001$ & 0,26 & $\frac{0,015}{0,008}$ \\
\hline ГАП & $\frac{3,3 \pm 1,0}{1,7-6,9}$ & $\begin{array}{l}<0,001 \\
<0,001\end{array}$ & $<0,001$ & 0,001 & 0,012 & 0,030 & $\frac{0,13}{0,003}$ \\
\hline ТЗФВ, $\mathrm{M \Gamma} / \mathrm{AM}^{3}$ & $\frac{932 \pm 446}{251-2170}$ & $\frac{0,33}{0,33}$ & 0,30 & $<0,001$ & 0,35 & 0,39 & 0,34 \\
\hline$\frac{\Phi B}{\mathrm{~T}}_{0} \overline{\Phi B}, \%$ & $\frac{50 \pm 23}{15-98}$ & $\frac{0,015}{0,002}$ & 0,040 & $<0,001$ & 0,001 & 0,22 & $\frac{0,78}{0,95}$ \\
\hline$\frac{\Phi B_{4}}{\mathrm{~T} 3 \Phi \mathrm{B}, \%}$ & $\frac{54 \pm 23}{21-130}$ & $\frac{0,024}{0,005}$ & 0,09 & $<0,001$ & 0,16 & 0,41 & 0,73 \\
\hline $\mathrm{A}_{\mathrm{M} \Phi \mathrm{MO}} \times 10^{2}, \mathrm{e}_{\mathrm{A}}$ & $\frac{8,9 \pm 4,9}{0,7-26,8}$ & $\frac{0,75}{0,92}$ & 0,14 & $<0,001$ & 0,39 & 0,38 & 0,86 \\
\hline $\begin{array}{l}\mathrm{A}_{\mathrm{M} \Phi \mathrm{MO}} / \Phi \mathrm{B}_{0} \\
\mathrm{e}_{\mathrm{A} \cdot} \mathrm{x}_{\mathrm{AM}}^{3} / \Gamma\end{array}$ & $\frac{0,26 \pm 0,18}{0,02-0,99}$ & $\frac{0,77}{0,43}$ & 0,016 & $<0,001$ & 0,98 & 0,014 & 0,77 \\
\hline 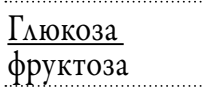 & $\frac{0,9 \pm 0,05}{0,8-1,0}$ & $\frac{\leq 0,001}{0,004}$ & 0,017 & $<0,001$ & 0,11 & - & 0,55 \\
\hline ВК/ЯК & $\frac{3,4 \pm 1,4}{1,6-7,3}$ & $\frac{0,07}{0,014}$ & 0,028 & 0,76 & 0,59 & 0,35 & 0,80 \\
\hline
\end{tabular}

Примечание: ${ }^{1}$ числитель - среднее значение \pm стандартное откмонение; знаменатемь - Аиапазон

Амя производства вин значениями $\mathrm{A}_{\mathrm{Mфмо}}$ : менее ими равным 0,07 еА. Отношение концентраций винной и ябцочной кислот в винограде из западных районов Предгорной и Степной зоны превышало $(\alpha<0,003)$ значения показателя в винограде из Южнобережной зоны в среАнем в 1,5 раза, достигая $3,9 \pm 1,5$. Статистически значимых отличий величин показателей ТЗФВ и МФМО/

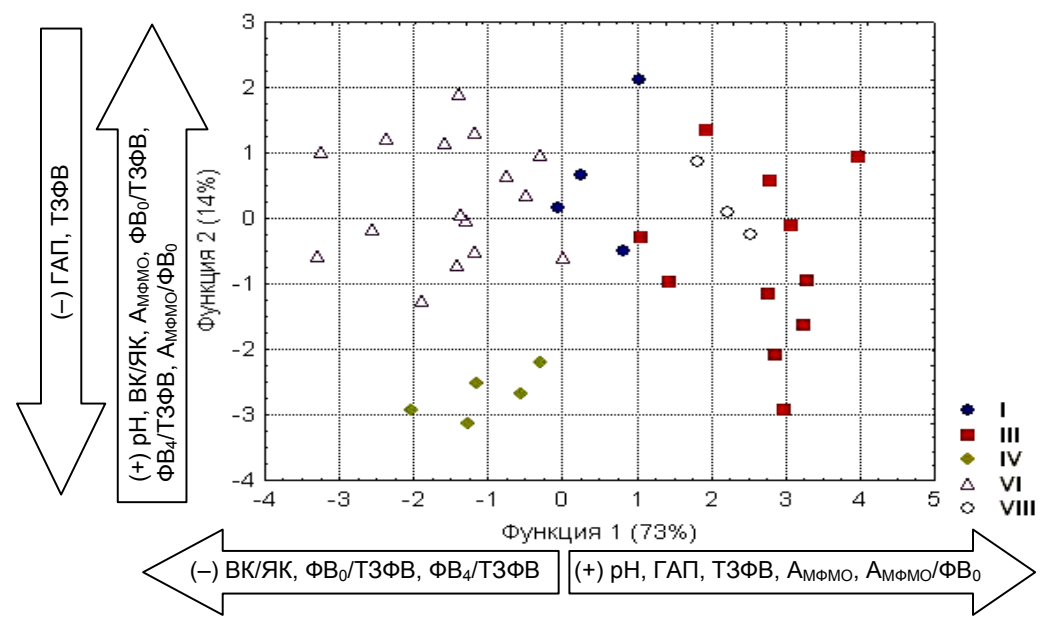

Рис. 1. Распределение винограда из разных районов произрастания по совокупности показателей

Fig. 1. Distribution of grapes from various growth regions by combination of parameters 
Таблица 2. Диапазоны варьирования показателей, дифференцирующих виноград по району произрастания Table 2. Parameter variation ranges differentiating grapes by growth regions

\begin{tabular}{|c|c|c|c|c|c|}
\hline \multirow{4}{*}{ Показатемь } & \multicolumn{5}{|c|}{ Природная зона } \\
\hline & \multicolumn{3}{|c|}{ Южнобережная } & Предгорная & Степная \\
\hline & \multicolumn{5}{|c|}{ почвенно-кмиматический район } \\
\hline & I & III & IV & VI & VIII \\
\hline $\mathrm{pH}$ & $3,36 \pm 0,22$ & $3,46 \pm 0,24$ & $3,31 \pm 0,17$ & $3,22 \pm 0,17$ & $3,40 \pm 0,08$ \\
\hline ГАП & $3,6 \pm 1,1$ & $3,8 \pm 1,1$ & $3,4 \pm 0,3$ & $2,8 \pm 0,6$ & $3,1 \pm 1,0$ \\
\hline $\mathrm{T} 3 Ф \mathrm{~B}, \mathrm{Mr} / \mathrm{AM}^{3}$ & $908 \pm 524$ & $833 \pm 448$ & $1077 \pm 499$ & $1009 \pm 395$ & $1086 \pm 330$ \\
\hline$\Phi B_{0} / \mathrm{T} З \Phi \mathrm{B}, \%$ & $53 \pm 22$ & $58 \pm 28$ & $33 \pm 7$ & $45 \pm 20$ & $27 \pm 4$ \\
\hline$\Phi B_{4} / \mathrm{T} З Ф \mathrm{~B}, \%$ & $55 \pm 25$ & $63 \pm 25$ & $39 \pm 18$ & $51 \pm 20$ & $31 \pm 4$ \\
\hline 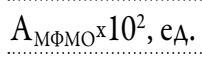 & $9,4 \pm 5,4$ & $8,6 \pm 3,6$ & $5,4 \pm 4,4$ & $9,0 \pm 5,4$ & $6,3 \pm 1,1$ \\
\hline $\begin{array}{l}\mathrm{A}_{\mathrm{M} \Phi \mathrm{MO}} / \Phi \mathrm{B}_{0}, \\
\mathrm{e}_{\mathrm{A} .} \times \mathrm{x}^{3} / \mathrm{r}\end{array}$ & $0,27 \pm 0,19$ & $0,25 \pm 0,14$ & $0,20 \pm 0,19$ & $0,26 \pm 0,16$ & $0,24 \pm 0,10$ \\
\hline BK/ЯK & $2,6 \pm 1,0$ & $2,7 \pm 0,6$ & $2,0 \pm 0,5$ & $3,9 \pm 1,6$ & $3,4 \pm 0,7$ \\
\hline
\end{tabular}

ФВ в винограде по исследуемым районам его произрастания не выявцено, оАнако их учет в совокупности показателей значительно улучшает Аискриминирование винограда по месту произрастания.

Аифференциация технологических параметров винограАа по районам его произрастания отразимась на Аисперсии показателей сухих виноматериалов (табц. 3). Выявцено наАичие прямой корремяционной зависимости концентрации титруемых кислот, величины $\mathrm{pH}$, соотношения концентраций винной и яблочной кислот в винограде и виноматериацах $(\mathrm{r}=0,6-0,7$ при $\alpha<0,01)$.

Как следует из табц. 3, наибомьшие концентрации титруемых кислот $\left(7,4 \pm 1,2\right.$ г/ $\left.\mathrm{AM}^{3}\right)$, значения ВК/ЯК и наименьшие величины $\mathrm{pH}(3,19 \pm 0,20)$ были определены в виноматериа$\Lambda$ ах из винограда, произрастающего в VI районе. Содержание сахаров в винограде и величина рН сусла являются значимыми факторами накопмения глицерина в винах как вторичного продукта спиртового брожения [21]: в исследуемой выборке корреляция значений показателей составляма 0,6 при $\alpha<0,0001$. Наибомьшая концентрация гмицерина $(6,9 \pm 0,8$ г/ $\mathrm{AM}^{3}$ ) опреАелена в виноматериамах из винограда, произрастающего в III районе и отмичающегося наибольшими значениями ГАП и рН.

Таблица 3. Диапазоны варьирования показателей виноматериалов, отличающиеся по району произрастания винограда

Table 3. Wine parameter variation ranges varied by grapvine growth region

\begin{tabular}{|c|c|c|c|c|c|c|}
\hline \multirow{3}{*}{ Показатемь } & \multicolumn{5}{|c|}{ Среднее значение \pm стандартное откмонение } & \multirow{3}{*}{$\begin{array}{l}\text { Уровень } \\
\text { значи- } \\
\text { мости } \alpha\end{array}$} \\
\hline & \multicolumn{5}{|c|}{ почвенно-кмиматический район } & \\
\hline & I & III & IV & VI & VIII & \\
\hline $\begin{array}{c}\text { Массовая концентрация: } \\
\text { титруемых кислот, г/Ам }\end{array}$ & $6,8 \pm 0,9$ & $6,5 \pm 1,1$ & $6,0 \pm 1,0$ & $7,4 \pm 1,2$ & $6,3 \pm 0,9$ & 0,0012 \\
\hline $\begin{array}{l}\text { фенольных веществ, } \\
\text { мГ/АM }\end{array}$ & $307 \pm 51$ & $304 \pm 73$ & $264 \pm 46$ & $244 \pm 93$ & $291 \pm 84$ & 0,0015 \\
\hline глицерина, г/Ам ${ }^{3}$ & $5,5 \pm 0,6$ & $6,9 \pm 0,8$ & $6,0 \pm 1,5$ & $6,0 \pm 0,9$ & - & $<0,0001$ \\
\hline $\mathrm{pH}$ & $3,30 \pm 0,18$ & $3,26 \pm 0,27$ & $3,52 \pm 0,09$ & $3,19 \pm 0,20$ & $3,38 \pm 0,16$ & 0,0051 \\
\hline $\mathrm{dEh} / \Phi \mathrm{B} \times 10^{2}, \mathrm{MB} \mathrm{AM}^{3} / \mathrm{M \Gamma}$ & $48,5 \pm 15,3$ & $27,1 \pm 19,8$ & $73,4 \pm 13,7$ & $69,7 \pm 16,1$ & - & $<0,0001$ \\
\hline ВК/ЯК & $1,2 \pm 1,0$ & $2,8 \pm 2,0$ & $1,2 \pm 1,5$ & $3,7 \pm 2,0$ & - & $<0,0001$ \\
\hline
\end{tabular}

Наибольшей концентрацией феномьных веществ отмичались виноматериалы из винограда, произрастающего в I-м и III-м районах, Аля которого характерна высокая способность к отАаче фенольных веществ в сусло при прессовании целых ягоА. В имеющемся массиве Аанных выявцена положительная корреляция $(r=0,6)$ межАу этими показатемями винограда и виноматериалов, значимая при $\alpha<0,05$. Не менее важным фактором формирования фенольного комплекса вин явцяется монофенолмонооксигеназная активность сусла, о чем свидетельствует обратная корреляционная зависимость этих показателей ( $\mathrm{r}=-0,66$, при $\alpha<0,05)$, обусловленная ферментативной помимеризацией мабимьных фракций фенольных компонентов, их конАенсацией и сеАиментацией на стадии переработки винограда. Совокупный учет по-

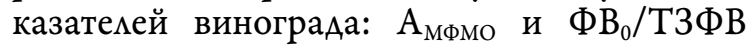
- предопределяет концентрацию фенольных веществ в виноматериалах (при равных усмовиях переработки винограда) при уровне значимости $\alpha<0,0001$. Это объясняет тот факт, что виноматериалы, полученные из винограда, произрастающего в VI-м районе и характеризующегося величиной $\Phi \mathrm{B}_{0} / \mathrm{T} З Ф \mathrm{~B}$ в среАнем $45 \%$ и $\mathrm{A}_{\text {Мфмо }}-0,09$ еА., отличались наименьшей концентрацией фенольных компонентов. Наибольшей окисленностью феноцьного комплекса $(\mathrm{dEh} / \Phi \mathrm{B}=27,1 \pm 19,8 \mathrm{мB}$ $\mathrm{AM}^{3} / \mathrm{Mr}$ ) характеризовацись виноматериалы, полученные из винограда, произрастающего в горно-долинном приморском районе и от-

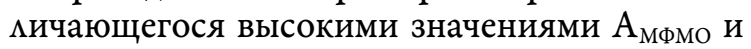
$\mathrm{pH}$. По Аругим показателям виноматериалов, определяемых в работе, статистически значимой разницы значений в зависимости от района произрастания винограда не выявлено.

Совокупность показателей, представменных в табл. 3, Аифференцировака образцы виноматериалов по 5 районам произрастания винограда с ошибкой менее $5 \%$ (Wilks L. $<0,094, \alpha<0,00001)$. Апробация системы показателей, проведенная на производственных образцах столовых вин с защищенным географическим указанием «Крым», показаца, что показатеми хорошо кмастеризуют вина крымских производителей, расположенных в разных географических районах Крыма (рис. 2).

Таким образом, в ходе проведенных исследований выявлены взаимосвязанные показате и, учитывающие особенности оксидазной системы, фенольного и углеводно-кислотного комплексов винограда, белых столовых виноматериалов и вин и в сово- 


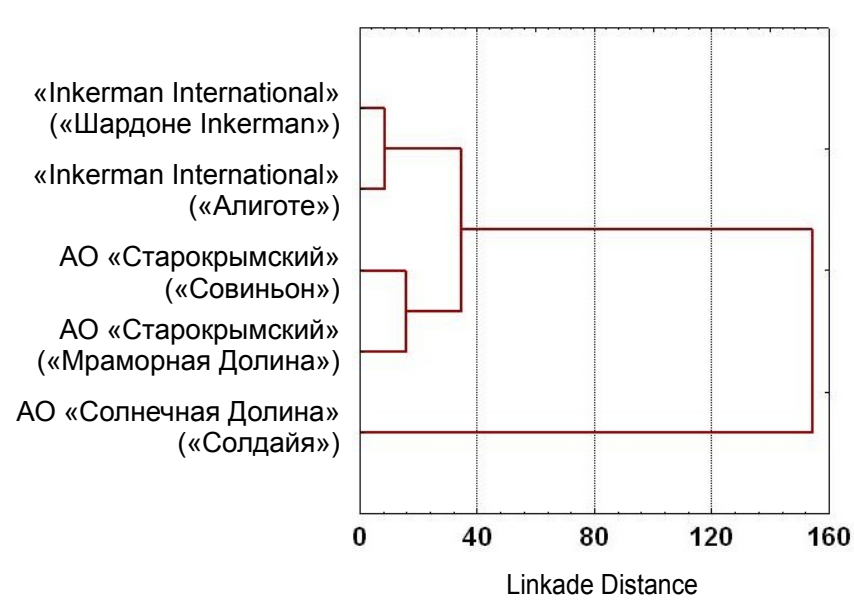

Рис. 2. Кластеризация белых вин крымских производителей из разных почвенно-климатических районов по совокупности показателей

Fig. 2. Clusterization of white Crimean wines from various soil-climatic regions by combination of parameters

купности Аифференцирующие их по географическому происхожАению.

\section{Заключение}

По результатам систематизации и статистической обработки многолетних экспериментацьных данных о составе и технологических свойствах винограАа, виноматериалов и вин из разных почвенно-кмиматических районов опредемена система физико-химических показателей, взаимосвязанных с качеством объектов и Аифференцирующих их по месту произрастания винограда. В симу указанных особенностей система

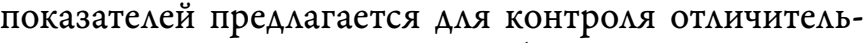
ных качественных признаков белых столовых вин, обусловленных происхожАением, в ходе всего техно-

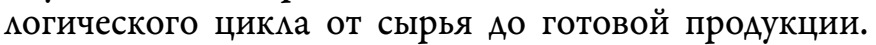
Установлены Аиапазоны варьирования показателей по виноградарско-винодельческим районам Крыма и роль природных факторов в их формировании.

Представленная работа явцяется этапом комплексных исследований, направленных на развитие отечественного виноделия с географическим статусом. В части совершенствования контроля качества и производства этой категории вин Аамьнейшие исслеАования предусматривают обоснование и вкАючение в систему контроця комплексных показателей, учитывающих технологические и биотехнологические особенности производства вин на разных предприятиях (вкцючая ароматобразующий комплекс и сенсорные профили), а также создание информационных модемй [23] параметров винограда - вина Аля каждого конкретного географического объекта (микрозоны) и/ими преАприятия, сорта винограда и марки вина.

\section{Источник финансирования}

Работа выполняется в рамках Государственного задания № 0833-2019-0022.

\section{Financing source}

The study was conducted under public assignment № 0833-2019-0022.

\section{Конфликт интересов}

Не заявлен.

\section{Conflict of interests}

Not declared.

\section{Благодарности}

Авторы выражают благодарность сотрудникам маборатории химии и биохимии вина ФГБУН «ВННИИВиВ «Магарач» РАН» за помощь в реа$\Lambda$ изации хроматографических методов анакиза.

\section{Список литературы/ References}

1. Huang X.-Y., Jiang Z.-T., Tan J. et al. Geographical Origin Traceability of Red Wines Based on Chemometric Classification via Organic Acid Profiles. Journal of Food Quality. 2017. Vol.2017. Article ID 2038073. 7 p. DOI: https:// doi.org/10.1155/2017/2038073

2. Gnilomedova N.V., Anikina N.S., Gerzhikova V.G. Profile of sugars in a grape-wine system as the identifying indicator of the authenticity of wine products. Foods and Raw Materials. 2018. Vol.6. №1. pp. 191-200. DOI: https://doi. org/10.21603/2308-4057-2018-1-191-200

3. Jaitz L., Siegl K., Eder R., Rak G., Abranko L., Koellensperger G., Hann S. LC-MS/MS analysis of phenols for classification of red wine according to geographic origin, grape variety and vintage. Food Chemistry. 2010. Vol.122. Iss.1. pp. 366-372.

4. Galgano F., Caruso M., Perretti G., Favati F. Authentication of Italian red wines on the basis of the polyphenols and biogenic amines. European Food Research and Technology. 2011. Vol.232. №1. pp. 889-897. DOI: https://doi.org/10.1007/ s00217-011-1457-1

5. González-Barreiro C., Rial-Otero R., Cancho-Grande B., Simal-Gándara J. Wine aroma compounds in grapes: a critical review. Critical Reviews in Food Science and Nutrition. 2015. Vol.55. №1. pp. 202-218. DOI: https://doi.org/10.1080/1040 8398.2011.650336

6. Xie Sh., Lei Y., Wang Y., Wang X. J., Ren R., Zhang Zh. Influence of continental climates on the volatile profile of Cabernet Sauvignon grapes from five Chinese viticulture regions. Plant Growth Regulation. 2019. Vol.87. Iss.1. pp. 83-92.

7. Bouloumpasi E., Soufleros E.H., Tsarchopoulos C. Biliaderis C.G. Primary amino acid composition and its use in discrimination of Greek red wines with regard to variety and cultivation region. Vitis. 2002. Vol.41. №4. pp. 195-202.

8. Paneque P., Álvarez-Sotomayor M.T., Clavijo A., Gómez I.A. Metal content in southern Spain wines and their classification according to origin and ageing. Microchemical Journal. 2010. Vol.94. Iss. 2. pp. 175-179. DOI: https://doi.org/10.1016/j. microc.2009.10.017

9. Sen I., Figen T. Characterization and Classification of Turkish Wines Based on Elemental Composition. Am. J. Enol. Vitic. 2014. №65. Iss. 1. pp. 134-142.

10. Titarenko V.O., Khalafyan A.A., Temerdashev Z.A., Kaunova A.A., Ivanovets E.A. Application of Statistical Methods for Classification of Varietal and Regional Origin of White Wines. Inorganic Materials. 2018. Vol.54. Iss. 14. pp. 1435-1442.

11. Tescione I., Marchionni S., Mattei M., Tassi F., Romano C., Conticelli S. A comparative ${ }^{87} \mathrm{Sr} /{ }^{86} \mathrm{Sr}$ study in Red and White wines to validate its use as geochemical tracer for the geographical origin of wine. Procedia Earth and Planetary Science. 2015. Vol.13. pp. 169-172.

12. Kolesnov A., Zenina M., Tsimbalaev S., Tereshenko G., Torshina L., Anikina N., Gnilomedova N., Gerzhikova V., Egorov E., Guguchkina T., Prakh A., Antonenko M. Massspectrometric study on ${ }^{13} \mathrm{C} /{ }^{12} \mathrm{C}$ carbon and ${ }^{18} \mathrm{O} /{ }^{16} \mathrm{O}$ oxygen stable isotopes distributions in grapes and wines from the Black Sea regions. BIO Web Conf. 41st World Congress of Vine and Wine. 2019. Vol.12. Article number 02036. 6 p. DOI: 
https://doi.org/10.1051/bioconf/20191202036

13. Оганесянц Л.А., Панасюк А.Л., Кузьмина Е.И., Яланецкий А.Я., Загоруйко В.А. Вариации отношений изотопов углерода этанола вин в зависимости от географического положения виноградников // «Магарач». Виноградарство и виноделие. 2017. № 4. С. 38-40.

[Oganesyants L.A., Panasyuk A.L., Kuzmina E.I.,Yalanetskii A.Ya., Zagorouiko V.A. Ratio variations of ethanol carbon isotopes in wines based on vineyard geographical location. Magarach. Vinogradarstvo $i$ vinodelie= Magarach. Viticulture and Winemaking. 2017. №4. pp. 38-40 (in Russian)].

14. Fan Sh., Zhong Q., Gao H., et al. Elemental profile and oxygen isotope ratio $\left({ }^{818} \mathrm{O}\right)$ for verifying the geographical origin of Chinese wines. Journal of Food and Drug Analysis, 2018. Vol. 26, iss. 3. pp. 1033-1044. DOI: https://doi. org/10.1016/j.jfda.2017.12.009.

15. Horacek M., Kolar K., Hola M., et al. Investigation of geographic origin of wine from border regions: Potential limitations and possibilities of different analytical methods and combinations of methods to identify the correct side of the border. BIO Web Conf. 41st World Congress of Vine and Wine, 2019. Vol. 12. Article number 02032, 3 p. DOI: https:// doi.org/10.1051/bioconf/20191202032

16. Versari A., Laurie V.F., Ricci A., Laghi L., and Parpinelloa G.P. Progress in authentication, typification and traceability of grapes and wines by chemometric approaches. Food Research International, 2014. Vol. 60. pp. 2-18. DOI: https://doi. org/10.1016/j.foodres.2014.02.007

17. Остроухова Е.В., Пескова И.В., Рыбалко Е.А., Твардовская Л.Б. Влияние климатических факторов на технологические характеристики винограда красных сортов, произрастающих в различных регионах Республики Крым // «Магарач». Виноградарство и виноделие. 2015. № 2. С. 28-31

[Ostroukhova E.V., Peskova I.V., Rybalko E.A., Tvardovskaya L.B. The effect of climatic factors on the technological characteristics of red grape varieties cultivated in different regions of the Republic of the Crimea. Magarach. Vinogradarstvo $i$ vinodelie=Magarach. Viticulture and Winemaking. 2015. №2. pp. 28-31 (in Russian)].

18. Сборник основных правил, технологических инструкций и нормативных материалов по производству винодельческой продукции / Утв. Минсельхозпродом РФ 05.05.1998 г. - М.: Пищепромиздат, 1998. 242 с.

[Sbornik osnovnyh pravil, tekhnologicheskih instrukciy $i$ normativnyh materialov po proizvodstvu vinodelcheskoj produkcii [Collection of fundamental principles, progress guidelines and standards on wine production / Approved by the Ministry of Agriculture of the Russian Federation on 05.05.1998]. Moscow: Pishchepromizdat Publ. 1998. 242 p. (in Russian)].

19. Koundouras S. Environmental and viticultural effects on grape composition and wine sensory properties. Elements. 2018. Vol.14. №3. pp. 173-178.

20. Методы технохимического контроля в виноделии / Под ред. В.Г. Гержиковой. 2-е издание. Симферополь: Таврида, 2009. 304 c.
[Metody teknokhimicheskogo kontrolya $v$ vinodelii. [Technochemical control methods in winemaking] / Edited by V.G. Gerzhikova. 2nd edition. Simferopol: Tavrida Publ., 2009. 304 p. (in Russian)].

21. Zhao X., Procopio S., Becker T. Flavor impacts of glycerol in the processing of yeast fermented beverages: a review. J. Food Sci Technol. 2015. №52 (12). pp. 7588-7598.

22. Vicens A., Fournand D., Williams P., Sidhoum L., Moutounet M., Cheynier V. Changes in Polysaccharide and Protein Composition of Cell Walls in Grape Berry Skin (Cv. Shiraz) during Ripening and Over-Ripening. J. Agric. Food Chem. 2009. №57 (7). pp. 2955-2960.

23. Остроухова Е.В., Пескова И.В., Пробейголова П.А., Луткова Н.Ю. Анализ технологических параметров винограда крымских аборигенных сортов: разработка информационных моделей //«Магарач». Виноградарство и виноделие. 2018. № 2 (104). C. 31-34.

[Ostroukhova E.V., Peskova I.V., Probeigolova P.A., Lutkova $\mathrm{N}$.Yu. Analysis of the technological parameters of the Crimean autochthonous grape cultivars: development of information models. Magarach. Vinogradarstvo i vinodelie=Magarach . Viticulture and Winemaking. 2018. №2 (104). pp. 31-34 (in Russian)].

24. Teixeira A., Eiras-Dias J., Castellarin S.D. Berry phenolics of grapevine under challenging environments. International journal of molecular sciences. 2013. №14. pp. 18711-18739.

25. Ostroukhova E., Peskova I., Vyugina M., Levchenko S.V. The study of the phenolic complex composition and the antioxidant activity of white grape cultivars. Acta Horticulturae. 2018. Vol.1205. pp. 327-337. DOI: https://doi. org/10.17660/ActaHortic.2018.1205.38.

26. Остроухова Е.В., Пескова И.В., Пробейголова П.А., Луткова Н.Ю., Зайцева О.В., Еременко С.А. Качество винограда как фактор развития виноделия с географическим статусом // «Магарач». Виноградарство и виноделие. 2018. № 3 (105). C. 77-79.

[Ostroukhova E.V., Peskova I.V., Probeigolova P.A., Lutkova N.Yu., Zaitseva O.V., Yeremenko S.A. Grape quality as a factor for the development of winemaking with geographical status. Magarach. Vinogradarstvo $i$ vinodelie= Magarach. Viticulture and Winemaking. 2018. №3 (105). pp. 77-79 (in Russian)].

27. Остроухова Е.В., Пескова И.В., Погорелов Д.Ю. Профиль органических кислот винограда белых сортов, произрастающих в Крыму // Плодоводство и виноградарство Юга России. 2019. №56 (02). С. 122-132. DOI: https://doi. org/10.30679/2219-5335-2019-2-56-122-132

[Ostroukhova E.V., Peskova I.V., Pogorelov D.Yu. The organic acid profile of white grapes varieties growing in Crimea. Fruit-Growing and Viticulture of South of Russia. 2019. № 56 (02). pp. 122-132 (in Rassian)].

28. Методы биохимического исследования растений / Под ред. А. И. Ермакова. 2-е издание. Ленинград: Колос, 1972. $457 \mathrm{c}$.

[Metody biokhimicheskogo issledovaniya rasteniy [Methods of biochemical research of plants] / Edited by A.I. Yermakov. 2nd edition. Leningrad: Kolos Publ., 1972. 457 p. (in Russian)].

ORCID ID:

Остроухова E.B. https://orcid.org/0000-0003-0638-9187

Пескова И.В. https://orcid.org/0000-0002-5107-518X

Пробейголова П.А. https://orcid.org/0000-0003-4442-8538

Луткова H.Ю. https://orcid.org/0000-0002-8126-7596 